Canadian Journal of Soil Science Revue canadienne de la science du sol

\title{
The Saskatchewan Shelterbelt Inventory
}

\begin{tabular}{|r|l|}
\hline Journal: & Canadian Journal of Soil Science \\
\hline Manuscript ID & CJSS-2016-0098.R1 \\
\hline Danuscript Type: & Special Issue Paper (Please select below) \\
\hline Complete List of Authors: & $\begin{array}{l}\text { Piwowar, Joseph; University of Regina, Department of Geography \& } \\
\text { Environmental Studies } \\
\text { Amichev, Beyhan; University of Saskatchewan, Soil Science } \\
\text { van Rees, Ken; University of Saskatchewan, Soil Science/agroforestry } \\
\text { research chair }\end{array}$ \\
\hline Keywords: & $\begin{array}{l}\text { Agri-environmental Indicators, Biomass, Buffer strips, Carbon, Greenhouse } \\
\text { gas }\end{array}$ \\
\hline &
\end{tabular}




\title{
The Saskatchewan Shelterbelt Inventory
}

\author{
Joseph M. Piwowar ${ }^{1}$ \\ Beyhan Y. Amichev² \\ Ken C.J. Van Rees ${ }^{2}$
}

\begin{abstract}
Shelterbelts represent a significant carbon reserve on the agricultural Prairie landscape and knowledge of their extent can be of importance to atmospheric carbon mitigation strategies. We describe the creation of a detailed inventory of the shelterbelts across the agricultural region of Saskatchewan. A total of 262,000 shelterbelts covering over $51,000 \mathrm{~km}$ were identified by species composition, row width, stand condition, and type. This inventory is an important baseline for monitoring changes in prairie agroforestry systems arising from climate change and land use conversion.
\end{abstract}

Keywords: FlySask aerial photographs, farm and field shelterbelts, on-screen digitizing, GIS shapefile

\footnotetext{
${ }^{1}$ Department of Geography and Environmental Studies, University of Regina, Regina SK, S4S 0A2, Canada. Email: joe.piwowar@uregina.ca.

${ }^{2}$ Department of Soil Science, University of Saskatchewan, Saskatoon, SK.
} 


\section{The Saskatchewan Shelterbelt Inventory}

\section{Introduction}

A shelterbelt is a row of trees or shrubs that grows along field boundaries, adjacent to roads and waterways, and around farmyards and livestock facilities (Agriculture and Agri-Food Canada, 2015). While most shelterbelts are planted from seedlings, a small proportion are left as remnants from the clearing of woodlots. Shelterbelts have been used to mitigate the effects of soil erosion due to wind, protect homes, crops and livestock, control snow blowing over roads, and provide wildlife habitat (Wiseman et al., 2009).

Shelterbelt agroforestry systems have been planted in Saskatchewan for more than a century, becoming an integral part of the Prairie landscape. From 1888 to 2014, the Agriculture and Agri-Food Canada Agroforestry Development Centre (ADC) at Indian Head, Saskatchewan distributed over 600 million trees to farmers across the Prairie Provinces.

Recent attention to the impacts of greenhouse gases (GHG) on the global climate system has focused attention on the carbon sequestration potential of shelterbelts. Shelterbelts represent a significant carbon reserve on the agricultural Prairie landscape and Kort and Turnock (1999) estimated that if a shelterbelt enhancement program planted six million trees a year, almost 0.4 million tonnes of atmospheric carbon would be sequestered. Over the past eighty years, Amichev et al. (2016) calculated that more than 130,000 tonnes of carbon have been sequestered in tree biomass and the soils of white spruce shelterbelts in Saskatchewan alone. Furthermore, the recognized value of shelterbelts as a GHG mitigation practice could also provide an additional incentive for not removing, but retaining, existing shelterbelts and for planting new ones. In a survey of producers and land owners throughout Saskatchewan, Rempel et al. (2016) found that the perceived benefits of shelterbelts were noneconomic and difficult to value within the producers' operations. 
While there are records of the numbers of shelterbelt trees shipped from the ADC and their destinations, until now there has not been an accurate inventory of where these trees were planted and how many are still growing. In recognition of the importance of shelterbelts on the Prairies, the objectives of this study were to (i) create an inventory of all planted and remnant shelterbelts across the $260,000 \mathrm{~km}^{2}$ agricultural region of Saskatchewan; and (ii) investigate ways in which this inventory could be completed as accurately and efficiently as possible.

\section{Methods}

We investigated new semi-automated technologies for efficiently identifying shelterbelt species using remote sensing data analysis. Previous research by Wiseman et al. (2009) suggested that objectoriented image analyses of the spectral reflectance, variance, and shape parameters of shelterbelts visible in digital aerial imagery had the potential to identify field shelterbelts with greater than $95 \%$ accuracy. Additionally, Liknes et al. (2010) successfully used object-oriented image analysis to generate predictive estimates of agricultural forest cover, although they did not inventory individual shelterbelts. It is noted that both Wiseman et al. (2009) and Liknes et al. (2010) focused on areas smaller than 250 $\mathrm{km}^{2}$ where the location and composition of the shelterbelts was well known.

Based on the findings of Wiseman et al. (2009) and Liknes et al. (2010), we evaluated the ability of object-oriented image analysis for the identification of linear features on air photo imagery and came to a similar positive conclusion (Olowokudejo \& Piwowar, 2013). Our study, however, was conducted to find linear clearings in forested regions; i.e., the vegetative opposite of finding tree rows on an open landscape. When we tried to apply our findings to the problem of identifying shelterbelts in agricultural regions, our results were not as conclusive. We discovered that the additional complexities of an agricultural landscape confounded the object-oriented classifier and although we could obtain reasonable results from a single air photo, they were not transferrable between scenes. That is, in order 
to identify shelterbelts with an accuracy of greater than $50 \%$, the object-oriented procedure required manual fine-tuning for each air photo sequence examined (Liknes et al., 2010; Pankiw and Piwowar, 2010).

We concluded that the level of effort required to accurately digitize shelterbelts on the 100,000 available aerial images of Saskatchewan by semi-automated methods exceeded the time that it would take to achieve the same results by manual on-screen techniques, so research on the semi-automated methods was set aside.

Thus, an inventory of all shelterbelts in the agricultural region of Saskatchewan was created through heads-up (on-screen) digitizing of aerial images obtained from the Saskatchewan Geospatial Imagery Collaborative (SGIC, FlySask.ca). The digital air photos were acquired between 2007 and 2012 at a nominal ground resolution of $60 \mathrm{~cm}$. We found the FlySask image resolution to be sufficient to observe shelterbelts as narrow as 2 metres (Pankiw and Piwowar, 2010).

Colour Infrared (CIR) images were selected as the primary data source over standard true-colour imagery because of the enhanced distinction of vegetated versus non-vegetated ground in the nearinfrared spectral region. This was especially important when working with the FlySask air photos because they were acquired during leaf-off conditions (i.e. in the spring and fall seasons). We found that, even for leafless vegetation, the near-infrared reflectance from shelterbelts was in greater contrast to the surrounding landscape than for images acquired mid-season. True-colour scenes from FlySask were examined when the CIR images were unclear and when supplemental detail was needed to validate shelterbelt identification.

After sorting the air photos into collections based on National Topographic System 1:250,000 map sheets, they were visually examined for shelterbelts at a scale of 1:5,000. At this scale, grid roads and field boundaries were used as guides to track the visual scan of the map sheet since they have a consistent cardinal orientation and a spacing of 1 mile $(1.6 \mathrm{~km})$. Rows of vegetation observed on the air 
photos were considered to be shelterbelts if they were nominally longer than $100 \mathrm{~m}$ and thinner than 20 $\mathrm{m}$. Shorter lengths were included when it was clear that the vegetated object was a segment of a larger shelterbelt, for example if it was a disconnected leg of a farmyard shelterbelt or an interrupted segment of a field shelterbelt. Both planted and remnant shelterbelts were included. As each shelterbelt was traced on the screen, it was assigned a set of attributes, as specified in Table 1.

Both farmyard and field shelterbelts were digitized as linear features. A field shelterbelt was one that was observed to be located in an agricultural field, away from any farm buildings. Field shelterbelts included the subtypes of: dugout shelterbelts, livestock shelterbelts, roadside shelterbelts, and riparian buffers (Agriculture and Agri-Food Canada, 2015). A farmyard shelterbelt was one that was observed to surround farm buildings on at least 2 sides, within a nominal distance of $50 \mathrm{~m}$. If a shelterbelt was observed to be protecting both a farmyard and a field, it was assigned to the farmyard category.

\section{Results and Discussion}

Over 262,000 individual shelterbelts were digitized (Figure 1, Table 2) in approximately 4,000 person-hours. We found $51,653 \mathrm{~km}$ of shelterbelts of various designs and age across the agricultural region of Saskatchewan. Narrow, single-row shelterbelts account for $85 \%$ of the plantings. Farmyard shelterbelts (total length of $29,754 \mathrm{~km}$ ) were more prevalent than field shelterbelts (total length of $21,899 \mathrm{~km})$. The majority of farmyard shelterbelts were planted with deciduous species, $74 \%$ of the farmyard shelterbelt total, followed by conifers $>$ shrubs $>$ mixed species. The majority of field shelterbelts were planted with shrub species, $71 \%$ of the field shelterbelt total (e.g., caragana), followed by deciduous > mixed > conifer species. Approximately $95 \%$ of the shelterbelts examined were in "good" condition, meaning that they were highly intact, with minimal gaps. 
The inventory was validated by comparing the shelterbelt data produced by different individuals digitizing the same area. The digitized location accuracy exceeded 90\%. Further validation against in situ data, particularly for the shelterbelt width, composition, and condition attributes is ongoing and will be updated as more field data becomes available.

In order to demonstrate the potential utility of the shelterbelt inventory, we joined it with soils data (Table 2, Figure 2). We found that deciduous species were consistently the preferred choice for farmyard shelterbelt planting across all soil zones. Shrub species were the preferred choice for field shelterbelts in the Brown, Dark Brown and Black soil zones, while conifer and deciduous species were the preferred choice in the Dark Gray and Gray soil zones. The total length of planted shelterbelts within a soil zone ranged from 23,274 $\mathrm{km}$ to $21 \mathrm{~km}$ in (descending order) the Dark Brown $(23,274)>$ Brown $(16,347)>$ Black $(10,940)>$ Dark Gray $(1,071)>$ Gray $(21)$ soil zones (Figure 2$)$. The ratio of farmyard:field shelterbelts ranged from 88:12 to 52:48 in (descending order) the Gray (88:12) > Black (74:26) > Dark Gray (73:27) > Dark Brown (53:47) > Brown (52:48) soil zones.

In addition to location, the other shelterbelt attributes collected during the digitizing process have considerable research value. For example, shelterbelt condition can be related to the ADC tree distribution records to estimate the age and longevity of the stands, and to ultimately estimate the success rate of the ADC prairie shelterbelt program. Further, since it has already been established that shelterbelts mitigate soil erosion, supplement soil moisture, and provide wildlife habitat, studies that examine how shelterbelt width affects these parameters can provide valuable information for new shelterbelt planting. Some other applications include identifying areas where shelterbelts appear to be most vulnerable for removal or die-out and mapping land-owner shelterbelt tree species preferences.

Amichev et al. (2015) described the importance of enumeration of shelterbelt establishment, maintenance, and diversity for policy makers. An inventory of shelterbelt designs (i.e., spacing, width, 
number of rows) is especially needed to determine the most effective designs to maximize GHG mitigation. It is expected that the effectiveness of shelterbelt designs to maximize GHG mitigation will vary by location, such as soil zone, and by the choice of planted shelterbelt species because of the differences in the tree growth conditions across the province and species growing properties. All this can be accomplished by the means of extensive field data collection aided by the shelterbelt inventory created in this study.

Shelterbelts have the potential to play a major role in climate change mitigation by sequestering significant amounts of atmospheric carbon dioxide $\left(\mathrm{CO}_{2}\right)$ into the soil and as biomass carbon in aboveground and belowground parts of planted shelterbelt trees or shrubs (Kort and Turnock, 1999; Amichev et al., 2016). This inventory can be used to help determine if the prairie agroforestry systems are disappearing because of climate change (Sauchyn et al., 2010) or through direct removal by producers (Rempel et al., 2016).

This research benefitted from the intuitive power of human discriminatory powers during the heads-up digitizing of the shelterbelts. However, the manual procedure was laborious, time-consuming and costly. Research into semi-automated image analysis methods that can consistently separate shelterbelts from other ground clutter in remotely sensed imagery is continuing. While it is very likely that a method to locate shelterbelts will be available within a couple of years, it may require several more years of development to provide the additional width, type, composition, and condition attributes that we obtained through manual digitizing.

\section{Conclusions}

An inventory of the shelterbelts in the agricultural regions of Saskatchewan was created by onscreen digitizing of CIR air photos. The location accuracy of the inventory was found to exceed $90 \%$; 
further validation against in situ data, particularly for the shelterbelt width, composition, and condition attributes is ongoing.

When we investigated new semi-automated technologies for efficiently identifying shelterbelt species using remote sensing object-oriented image analysis, we found them to be difficult to implement over a wide area. Continued research to address these shortcomings is needed.

The shelterbelt inventory of Saskatchewan described here can be combined with other data (e.g. soils and tree species) to make important contributions to our understanding of carbon cycling in agricultural environments. The inventory is an important baseline upon which future studies can be built. It would be very useful to repeat this inventory on decadal time scales, both where historical air photos are available and when new imagery is collected.

GIS shapefiles of the shelterbelt inventory of Saskatchewan can be obtained by contacting the first author of this paper.

\section{Acknowledgments}

Funding was provided by Agriculture and Agri-Food Canada (AAFC)'s Agricultural Greenhouse Gases Program (AGGP). The dedicated digitizing work by Joey Pankiw, Titus Olowokodejo, and Raid Amalki is gratefully appreciated.

\section{References}

Agriculture and Agri-Food Canada, 2015. Shelterbelt Planning and Establishment. [Online] Available at: http://www.agr.gc.ca/eng/science-and-innovation/agriculturalpractices/agroforestry/shelterbelt-planning-and-establishment

[Accessed 23 October 2016].

Amichev, B.Y., Bentham, M.J., Cerkowniak, D., Kort, J., Kulshreshtha, S., Larocque, C.P., Piwowar, J.M., Van Rees, K.C.J., 2015. Mapping and quantification of planted tree and shrub shelterbelts in Saskatchewan, Canada. Agroforestry Systems 89, 49-65. 
Amichev, B.Y., Bentham, M.J., Kurz, W.A., Laroque, C.P., Kulshreshtha, S., Piwowar, J.M., Van Rees, K.C.J., 2016. Carbon sequestration by white spruce shelterbelts in Saskatchewan, Canada: 3PG and CBM-CFS3 model simulations. Ecological Modelling 325, 35-46.

Kort, J., Turnock, R., 1999. Carbon reservoir and biomass in Canadian prairie shelter-belts. Agroforestry Systems 44, 175-186.

Liknes, G.C., Perry, C.H., Meneguzzo, D.M., 2010. Assessing Tree Cover in Agricultural Landscapes Using High-Resolution Aerial Imagery. Journal of Terrestrial Observation 2, 38-55.

Olowokudejo, T. \& Piwowar, J., 2013. Anthropogenic disturbance extraction using object-oriented image classification software: A comparison of Overwatch Feature Analyst and Definiens Developer. Prairie Perspectives: Geographical Essays, Volume 16

Pankiw, J., Piwowar, J., 2010. Seasonality of imagery: the impact on object-based classification accuracy of shelterbelts. Prairie Perspectives: Geographical Essays 13, 39-48.

Rempel, J.C., Kulshreshtha, S.N., Amichev, B.Y., Van Rees, K.C.J., 2016. Costs and Benefits of Adoption and Retention of Shelterbelts in Saskatchewan: Producers' Perception. Agroforestry Systems.

Sauchyn, D., Diaz, H.P., Kulshreshtha, S., 2010. The New Normal: The Canadian Prairies in a Changing Climate. Canadian Plains Research Center Press, Regina.

Wiseman, G.S., Kort, J., Walker, D.J., 2009. Quantification of shelterbelt characteristics using highresolution imagery. Agriculture, Ecosystems and Environment 131, 111-117. 


\section{Tables and Figures}

Table 1: Digitized shelterbelt attributes.

\begin{tabular}{|c|c|c|}
\hline Attribute & Values & Description \\
\hline \multicolumn{3}{|l|}{ Type } \\
\hline & Field & Shelterbelts growing in fields, typically along field boundaries. \\
\hline & Farmyard & Shelterbelts planted around farm buildings. \\
\hline \multicolumn{3}{|l|}{ Width } \\
\hline & Narrow & A shelterbelt composed of a single row of vegetation. \\
\hline & Medium & A shelterbelt composed of 2-3 rows of vegetation. \\
\hline & Wide & A shelterbelt composed of more than 3 rows of vegetation. \\
\hline \multicolumn{3}{|c|}{ Composition } \\
\hline & Grass & Shelterbelts composed primarily of grasses. \\
\hline & Shrubs & Shelterbelts composed primarily of shrubs. \\
\hline & Coniferous & Shelterbelts composed primarily of coniferous trees. \\
\hline & Deciduous & Shelterbelts composed primarily of deciduous trees. \\
\hline & Mixed & $\begin{array}{l}\text { Shelterbelts composed a mixture of shrubs and coniferous and } \\
\text { deciduous trees. }\end{array}$ \\
\hline & Undetermined & Shelterbelts whose vegetation type could not be determined. \\
\hline \multicolumn{3}{|l|}{ Condition } \\
\hline & Good & $\begin{array}{l}\text { Shelterbelts that are highly intact with minimal gaps; } \\
\text { between } 80-100 \% \text { of the shelterbelt remains. }\end{array}$ \\
\hline & Fair & $\begin{array}{l}\text { Shelterbelts that are mainly intact with few gaps; } \\
\text { between } 50-80 \% \text { of the shelterbelt remains. }\end{array}$ \\
\hline & Poor & $\begin{array}{l}\text { Shelterbelts that have considerable gaps and missing sections; } \\
\text { less than } 50 \% \text { of the shelterbelt remains. }\end{array}$ \\
\hline
\end{tabular}


Table 2. Saskatchewan shelterbelt inventory metrics by shelterbelt type and composition across the five soil zones in Saskatchewan.

\begin{tabular}{|c|c|c|c|c|c|c|c|c|c|}
\hline \multirow{2}{*}{$\begin{array}{l}\text { Shelterbelt } \\
\text { Type }\end{array}$} & \multirow[t]{2}{*}{ Composition } & \multirow[t]{2}{*}{ Metrics } & \multicolumn{5}{|c|}{ Soil Zone } & \multirow{2}{*}{$\begin{array}{c}\text { Farm or Field } \\
\text { Shelterbelt } \\
\text { Total }\end{array}$} & \multirow{2}{*}{$\begin{array}{l}\text { Grand } \\
\text { Total }\end{array}$} \\
\hline & & & Dark Brown & Black & Brown & Dark Gray & Gray & & \\
\hline \multirow[t]{2}{*}{ farmyard } & conifers & Cumulative length (km) & 1,599 & 1,762 & 676 & 263 & 8 & 4,309 & \\
\hline & & Percent (\%) from total & 3.1 & 3.4 & 1.3 & 0.51 & 0.016 & 8.3 & \\
\hline \multirow[t]{2}{*}{ farmyard } & deciduous & $(\mathrm{km})$ & 9,313 & 5,717 & 6,362 & 472 & 10 & 21,876 & \\
\hline & & $(\%)$ & 18 & 11 & 12 & 0.91 & 0.020 & 42 & \\
\hline \multirow[t]{2}{*}{ farmyard } & mixed & $(\mathrm{km})$ & 103 & 47 & 25 & 10 & & 186 & \\
\hline & & $(\%)$ & 0.20 & 0.092 & 0.049 & 0.020 & & 0.36 & \\
\hline \multirow[t]{5}{*}{ farmyard } & shrubs & $(\mathrm{km})$ & 1,406 & 521 & 1,424 & 32 & 0.4 & 3,384 & \\
\hline & & $(\%)$ & 2.7 & 1.0 & 2.8 & 0.062 & 0.001 & 6.6 & \\
\hline & & Farm Shelterbelt Total & & & & & & & \\
\hline & & $(\mathrm{km})$ & 12,422 & 8,048 & 8,488 & 778 & 19 & & 29,754 \\
\hline & & $(\%)$ & 24 & 16 & 16 & 1.5 & 0.037 & & 58 \\
\hline \multirow[t]{2}{*}{ field } & conifers & $(\mathrm{km})$ & 74 & 91 & 17 & 103 & 2 & 286 & \\
\hline & & $(\%)$ & 0.14 & 0.18 & 0.033 & 0.20 & 0.004 & 0.55 & \\
\hline \multirow[t]{2}{*}{ field } & deciduous & $(\mathrm{km})$ & 3,001 & 886 & 1,720 & 133 & 0.4 & 5,741 & \\
\hline & & $(\%)$ & 5.8 & 1.7 & 3.3 & 0.26 & 0.001 & 11 & \\
\hline \multirow[t]{2}{*}{ field } & mixed & $(\mathrm{km})$ & 249 & 38 & 101 & 12 & & 400 & \\
\hline & & $(\%)$ & 0.48 & 0.073 & 0.20 & 0.023 & & 0.77 & \\
\hline
\end{tabular}




\begin{tabular}{crrrrrr}
\hline $\begin{array}{c}\text { Field Shelterbelt Total } \\
(\mathrm{km})\end{array}$ & 10,852 & 2,892 & 7,859 & 293 & 3 & 21,899 \\
$(\%)$ & 21 & 5.6 & 15 & 0.57 & 0.005 & 42 \\
& & & & & & \\
\hline Grand Total (farm and field) & & & & & & 51,653 \\
$(\mathrm{~km})$ & 23,274 & 10,940 & 16,347 & 1,071 & 21 & 100 \\
$(\%)$ & 45 & 21 & 32 & 2.1 & 0.042 & \\
\hline
\end{tabular}




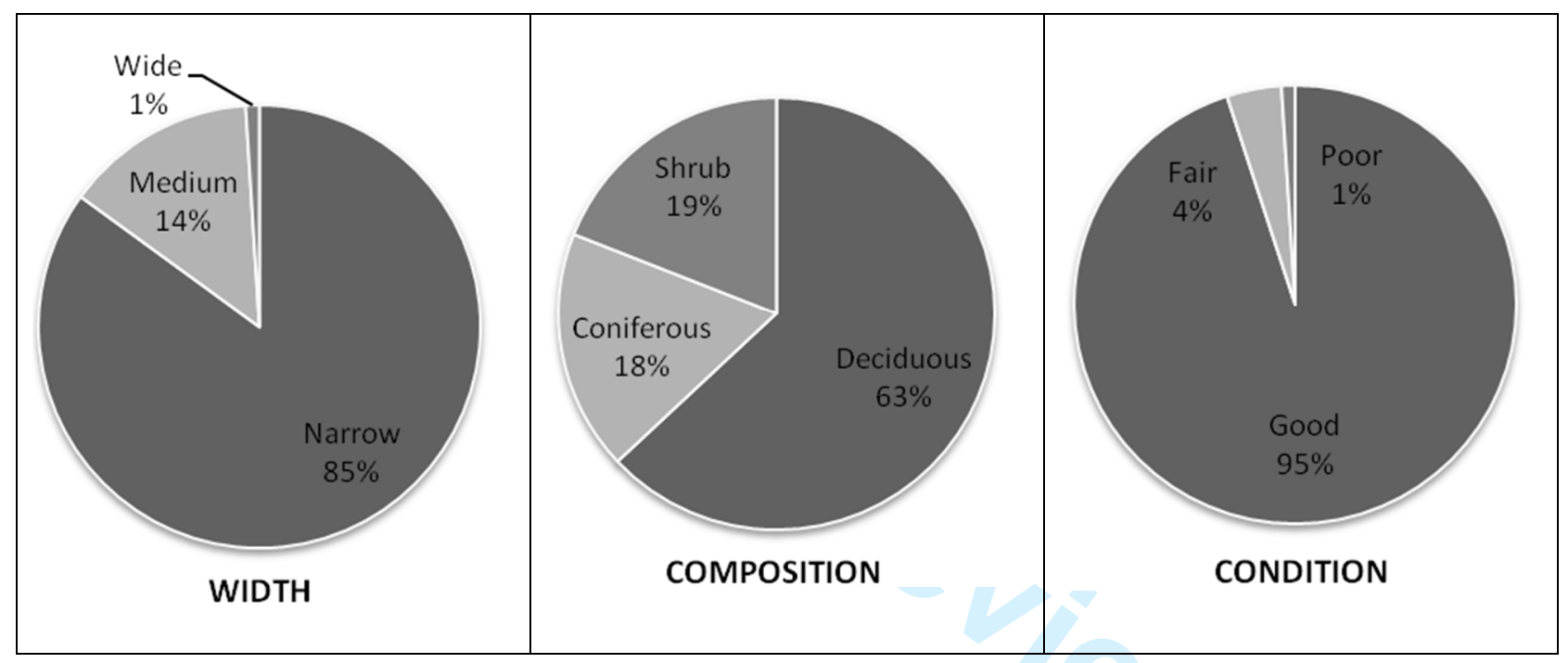

Figure 1. Digitized shelterbelt characteristics. 


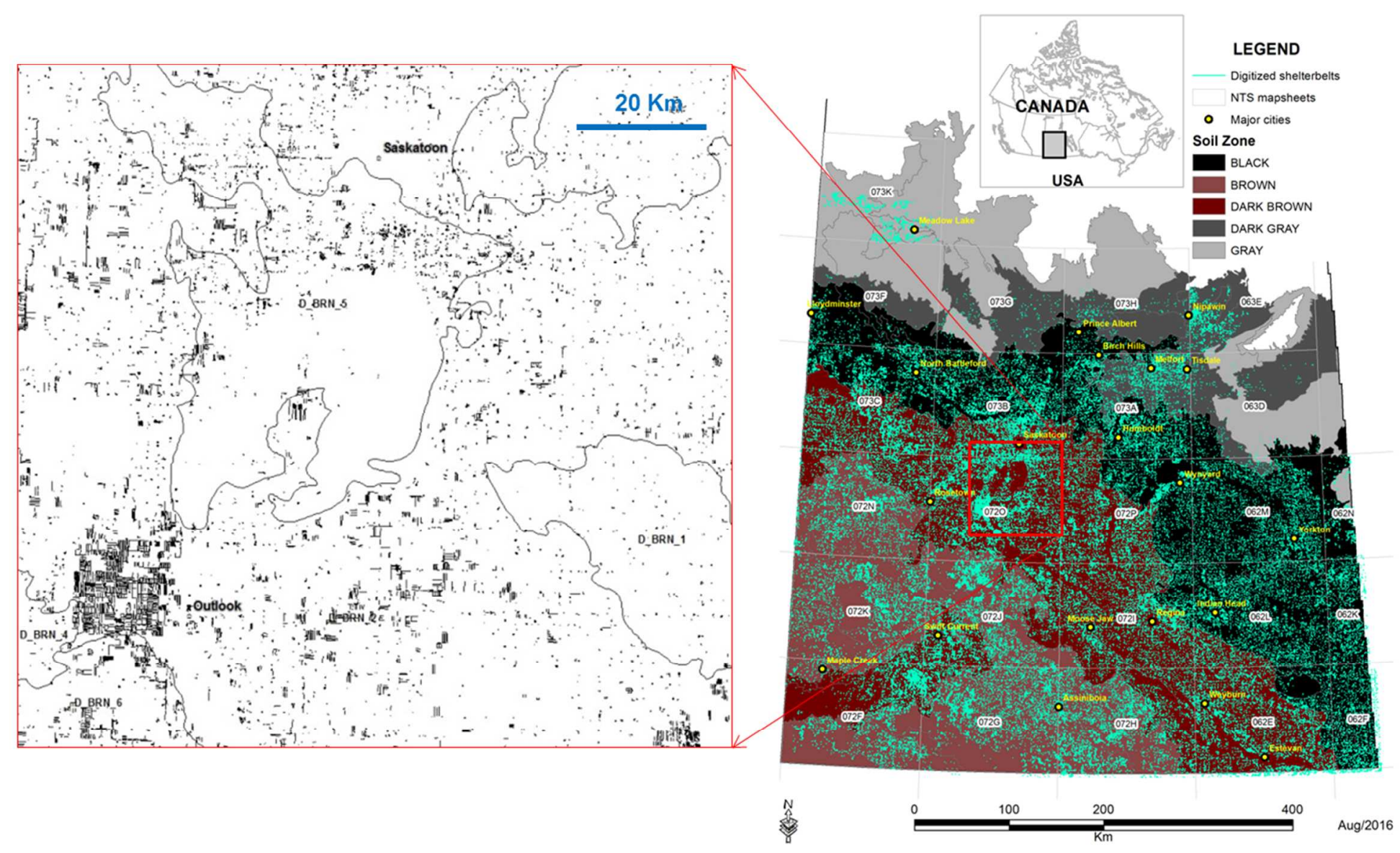

Figure 2. Distribution of digitized shelterbelts across the five soil zones in Saskatchewan. 